\title{
ORIENTASI DAN LAYANAN SANTRI ASING DI PESANTREN WALI BAROKAH KEDIRI JAWA TIMUR
}

\author{
ORIENTATION AND SERVICE FOR FOREIGN STUDENTS \\ IN PESANTREN WALI BAROKAH, KEDIRI, EAST JAVA
}

\author{
Munawiroh \\ Puslitbang Pendidikan Agama dan Keagamaan, Badan Litbang dan Diklat, Kementerian Agama \\ Jl. M.H. Thamrin No. 6 Jakarta Pusat, Daerah Khusus Ibukota Jakarta \\ email:mun.asrori@gmail.com
}

Naskah Diterima: 27 Agustus 2018; Direvisi: 24 September 2018; Disetujui: 08 Desember 2018

\begin{abstract}
This article is written based on the research focusing on foreign students in Pesantren (Islamic Boarding School) Wali Barokah Kediri. This research focused on the orientation (perspective and vision) and service for foreign students in the Pesantren. The research was conducted by using qualitative approach and descriptive method. Data source was obtained through observation, documentation studies, and in-depth interview with the Pesantren leaders, kiai/ustad (religious senior/teacher), and foreign students. The findings in this research were: 1) The foreign students in Pesantren Wali Barokah aimed to achieve Islamic theology or tafaqquh fiddin excellently, accurately, and completely (kaffah), 2) The parents of foreign students were also involved in learning activities in Pesantren Wali Barokah, 3) The foreign students' vision to study in pesantren is to be guided directly by ustad/ustazah (male and female teachers) who possess articulate Islamic theology (sanad keilmuan Islam) and are faithful to their academic performance. Furthermore, the students can particularly accomplish reading one of the Kutub Sittah holy books and memorize 30 Juz (part/section) of Alquran, and 4) The parents have their expectations that by sending their children to study in pesantren, they will be independent and become high quality human beings.
\end{abstract}

Keywords: Foreign student; Orientation; Pesantren Wali Barokah; Service

\begin{abstract}
Abstrak
Artikel ini merupakan hasil penelitian tentang santri asing di Pesantren Wali Barokah Kediri. Penelitian ini difokuskan pada orientasi (pandangan dan aspirasi) dan layanan asing yang belajar di pesantren tersebut. Penelitian ini menggunaakan pendekatan kualitatif dengan jenis penelitian deskriptif. Sumber data diperoleh melalui pengamatan, studi dokumen dan wawancara mendalam terhadap pimpinan pesantren, kiai/ustad dan santri asing. Hasil temuan penelitian ini antara lain: 1) santri asing belajar di pesantren Wali Barokah bertujuan untuk memperoleh Ilmu agama Islam atau tafaqquh fiddin secara baik, akurat dan lengkap (kaffah), 2) para orang tua santri asing juga samasama mengikuti pembelajaran di pesantren Wali Barokah, 3) Aspirasi santri asing belajar di pesantren yaitu memperoleh bimbingan langsung para ustad/ustazah yang memiliki sanad keilmuan yang jelas, serta dipertanggungjawabkan secara akademis. Seliaan itu, secara khusus mereka dapat mengkahatamkan salah satu dari kitab Kutub Sittah dan menghafal Alquran 30 Juz. 4) Sementara itu, harapan orang tua santri belajar di pesantren ini ingin anak-ananya menjadi manusia mandiri dan berakhlak mulia.
\end{abstract}

Kata Kunci: Layanan; Orientasi; Pesantren Wali Barokah; Santri asing 


\section{PENDAHULUAN}

Perkembangan pesantren saat ini, semakin diminati oleh masyarakat, baik masyarakat dalam negeri maupun luar negeri. Data menunjukan bahwa santri yang datang dari luar negeri sudah mencapai \pm 4000 santri yang menyebar di berbagai pesantren di Indoneia ${ }^{1}$. Santri asing yaitu santri yang belajar atau mondok di sebuah pondok pesantren atas kemauan santri sendiri yang dikirim ke sebuah pesantren di Indonesia oleh orang tua santri atau instnasi/lembaga, dengan tujuan untuk belajar ilmu pengetahuan agama dengan cara mempelajari kitab-kitab kuning (kutub at-turats) yang biasa dipelajari di pesantren tersebut. Pesantren tersebut di antarnya adalah Pondok Pesantren (PP) Amanatul Ummah Mojokerto Jawa Timur, PP Al-Khoirot Malang Jawa Timur, PP Kediri Jawa Timur, PP Modern Darussalam Gontor Ponorogo Jawa Timur, PP Wali Barokah LDII Kediri Jawa Timur, PP Al-Fatah Temboro Magetan Jawa Timur, PP Sirojul Mukhlasin Magelang Jawa Tengah, PP Wakhid Hasyim Semarang Jawa Tengah, PP Miftahul Ulum Pati Jawa Tengah, PP Darut Tauhid Purworejo Jawa Tengah, PP Al-Muslimin Pekalongan Jawa Tengah, PP Alwahdah Islamiyah Makassar, PP Hidayatullah Samarinda, dan lainnya.

Fokus penelitian ini adalah Pondok Pesantren (PP) Wali Barokah, salah satu pondok yang memiliki keunikan tersendiri dari pondok-pondok yang ada di Indonesia, yaitu memiliki sistem pembelajaran yang sangat kilat, yaitu dalam kurun waktu satu setengah, lulusan santri pondok ini sudah bisa mendapatkan gelar mubalig/mubaligoh pemula. Hal ini sangat berbeda jauh dengan pondok-pondok pesantren lainnya yang membutuhkan waktu lebih panjang atau sangat untuk bisa memperoleh gelar ustad/ustazah atau kiai muda.

Dengan keunikannya tersebut, banyak santri asing yang tertarik untuk datang dan belajar di PP Wali Barokah. dengan harapan mereka bisa belajar menguasai ilmu agama dengan cepat dan dapat mengimplementasi-

\footnotetext{
${ }^{1}$ Hasil Survey Puslitbang Pendidikan Agama dan Keagamaan Tahun 2018
}

kan dalam kehidupan sehari-hari sekaligus juga bisa mengajarkan kepada yang lainnya.

Dengan kehadiran santri asing, pondok dituntut untuk memberikan pelayanan yang baik, baik layanan administrasi maupun layanan akademik. Selain itu kehadiran santri asing, juga memiliki motivasi, orientasi, persepsi dan ekspektasi yang beragam. Terkait dengan orientasi, sebagai pandangan tentang studi Islam di Timur Tengah dan di Barat, meski selama ini diperdebatkan namun itulah sesungguhnya yang menjadi orientasi mengapa orang Islam tertarik untuk studi Islam ke Barat dan Timur.

Orietatasi muslim untuk studi Islam di Barat, dapat dipahami karena studi Islam di Barat telah berusaha keras menampilkan citra yang lebih adil dan penuh penghargaan terhadap Islam sebagai agama dan peradaban, dengan mengandalkan berbagai pendekatan dan metode yang lebih canggih dalam ilmuilmu sosial dan kemanusiaan, bahkan tidak jarang dipelopori oleh sarjana-sarjana Muslim sendiri. Sementara persolan ekspektasi santri asing terhadap pendidikan pesantren yang di dalamnya terkandung ingin memperoleh pengetahuan agama (tafaqquh fiddin). Sedangkan persoalan layanan santri asing di pesantren, pertanyaannya adalah apa strategi yang telah dilakukakn pesantren untuk melayani santri asing seiring pesatnya perkembangan ilmu pengetahuan dan teknologi serta semakin meningkatnya tuntutan kebutuhan hidup sosial masyarakat bukan saja dalam negeri tapi juga masyarakat luar negeri sebagai pelanggan pendidikan ${ }^{2}$

Menurut Muhammad Toha, alasan santri memilih pesantren sebagai tempat belajar mereka saat ini adalah sebagai berikut: pertama, keinginan sendiri sehingga diyakini bahwa proses di pesantren akan membawa dampak yang positif bagi mereka, sehingga berguna bagi masyarakat. Kedua, pihak lain seperti orang tua dan teman. Hal ini sebenarnya tidak perlu dipersoalkan karena yang penting mereka serius dalam menjalan-

\footnotetext{
${ }^{2}$ Tim peneliti Puslitbang Pendidikan Agama dan Keagamaan, 2018, "Desain Operasional penelitian Santri Asiang di Pondok Pesantren" Badan Litbang dan Diklat Kementerian Agama RI.
} 
kan kegiatan kepesantrenan, walaupun banyak yang melanggar kegiatan kepesantrenan. ${ }^{3}$

\section{Adapun terkait dengan layanan,} menurut Eryna, dkk. 2015, dua faktor yang sangat berpengaruh terhadap kepuasan santri adalah variabel Sarana Prasarana dan SDM tenaga pendidik dan kependidikan (Ustaz/ Ustazah/Kiai). Kurangnya sarana dan prasarana mengakibatkan menurunnya minat siswa/santri dan orang tua untuk belajar kepesantren. Sementara terkait dengan SDM, bawa para tenaga pendidik dan kependidikan dituntut mampu memberikan layanan baik administrasi maupun akademik kepada santri. Oleh karena itu untuk meningkatkan pelayanan kepada santri dipandang perlu pondok pesantren untuk meningkatkan kebersihan kamar mandi/WC, Tempat Tidur, Ruang belajar, dll. Memberikan pelatihan/ diklat dan beasiswa kepada Kiai, Ustad/Ustazah. ${ }^{4}$ Dengan adanya layanan tersebut diatas santri merasa puas dan nyaman belajar di pondok pesantren. Oleh karena itu dibutuhkan strategi dalam persoalan layanan santri asing di pesantren.

Penelitian yang dilakukan di PP Wali Barokah ini, untuk memperoleh informasi tentang pelayanan pesantren, baik kebersihan, ketersediaan fasilitas, dan pengembangan serta peningkatan keilmuan dan bakat santri yang sifatnya strategis. Terrmasuk di dalamnya layananan instansi terkait yaitu Kementerian Agama, Kemenkumham. Baik pesantren sendiri tempat para santri asing, belajar dan tinggal, maupun instansi terkait memiliki tanggung jawab masing-masing atas kebutuhan dan kesulitan yang dihadapi mereka, agar dapat memberikan pelayanan yang profesional dan berkualitas. Pelayanan terhadap santri dalam negeri maupun santri asing yang kurang berkualitas dan profesional sudah saatnya diubah menjadi pelayanan pendidikan pesantren yang berkualitas dan profesional. Jika pelayanan berkualitas dan profesional, hal itu akan mempengaruhi

${ }^{3}$ Muhammad Toha, 2014, Orientasi Santri Dalam Menempuh Pendidikan Pesantren Di Pamekasan" Dosen STAIN Pamekasan.

${ }^{4}$ Eryna, dkk, 2014, "Analisis Kualitas Layanan Pendidikan" Proseding Seminar Pendidikan Nasional, Univeritas Sebelas Maret, Surakarta. semangat para santri dalam mengikuti proses pembelajaran di pondok pesantren yang menjadi harapan mereka. Di sini juga menunjukkan pentingnya pondok pesantren menyusun strategi kedepan untuk meningkatkan kualitas layanan santri asing di pesantren.

Dari latar belakang tersebut di atas maka keberadaan santri asing yang berada di PP Wali Barokah menjadi sangat penting untuk dilakukan penelitian dari segi orientasi santri belajar di pondok pesantren dan layanan PP Wali Barokah terhadap santri asing yang belajar.

\section{METODOLOGI PENELITIAN}

Studi ini mengkaji tentang santri asing di PP Wali Barokah LDII Burengan, Banjaran Kediri, Jawa Timur. Penelitian dilaksanakan selama 15 hari, dengan menggunakan pendekatan kualitatif deskriptif. Pendekatan kualitatif dilakukan melalui pendalaman tentang santri asing di pesantren Indonesia. Pendekatan deskriptif dilakukan untuk mendeskripsikan mengenai fenomena nyata tentang santri asing di pesantren. Pengambilan data dilaksanakan dengan melakukan pengamatan setiap kegiatan dan melalui wawancara kepada informan. Sumber data diambil dari pihak-pihak terkait yaitu santri yang berasal dari luar negeri, pengurus pondok pesantren, ustad, masyarakat, dan inastansi terkait (Kemenag, Kemenkumham, dan Pemda setempat). Pengambilan data melalui, wawancara, observasi, dan dokumentasi.

Dari hasil penelitian ini diharapkan akan menjadi bahan kebijakan layanan santri asing di pesantren yang dibutuhkan bagi Direktorat Pendidikan Diniyah dan Pesantren Kementerian Agama RI. Selain itu juga sebagai bahan informasi kepada masyarakat yang memerlukannya.

\section{HASIL DAN PEMBAHASAN}

\section{Gambaran Umum Pesantren Wali Barokah}

Pondok Pesantren Wali Barokah, Burengan, Kota Kediri, merupakan salah satu pondok pesantren terbesar di Indonesia. PP Wali Barokah didirikan oleh KH. Nur Hasan Al Ubaidah dan Ahmad Ibroham pada tahun 
1951 yang dikenal dengan Pondok Pesantren Darul Hadis Burengan. Pondok pesantren yang menampung \pm 4.000 siswa (dari berbagai provinsi dan negara) menyerahkan pengelolaan Lembaga Karyawan Dakwah Islam (LEMKARI) pada 1972, sebab KH. Nur Hasan Al Ubaidah merasa sudah tua dan sudah lelah dalam mengelola pondok tersebut, maka beralihlah nama PP Darul Hadis menjadi PP Lemkari Burengan.

Pada tahun 1982 tepatnya hari Kamis, tanggal 11 Maret 1982 beliau wafat dan sebagai pengesahannya secara yuridis, pada tanggal 03 Mei 1983 para ahli waris yang diwakili oleh KH. Abdul Dhohir menyerahkan pengelolaan PP Burengan-Banjaran Kediri kepada pendiri Lemkari Raden Eddy Masiadi, Drs. Bachroni Hartanto, Soetojo Wirjo Atmodjo BA, Wijono BA, Drs. Nurhasjim yang dalam nota penyerahannya diwakili oleh Drs. Bachroni Hartanto untuk dan atas nama Direktorium Pusat Lemkari, yang saat itu Dia juga sebagai Ketua PP Lemkari BurenganBanjaran Kediri.

Selepas penyerahan, pondok pesantren ini mulai membangun berbagai sarana dan prasarana untuk mendukung kegiatan pondok pesantren berupa perkantoran, gedung DMC, Gedung Wali Barokah yang dijadikan ruang utama kegiatan belajar mengajar dan menara tertinggi di Indonesia yaitu Menara Asma'ul Husna. Sesuai dengan namanya menara ini tingginya 99 meter dengan kubah berlapis emas seberat $60 \mathrm{~kg}$. Menara Asma'ul Husna dapat dilihat dari berbagai pelosok Kota Kediri. Sebaliknya jamaah muslim dapat melihat seluruh penjuru Kota Kediri dari ketinggian setiap balkon menara. Menara Asma'ul Husna saat ini tercatat sebagai menara Islam tertinggi di Indonesia dan telah menjadi ikon (landmark) Kota Kediri yang sangat menonjol dan indah. Bandingkan dengan Monas Jakarta yang tingginya 132 meter (433 ft). Secara filosofi Menara Asma'ul Husna merupakan identitas LDII dan simbol kebesaran dan kebenaran Alquran dan Alhadis yang dibawa oleh LDII. Pada saat itu pula (1991) Lemkari berubah menjadi Lembaga Dakwah Islam Indonesia (LDII) otomatis pengelolaan pesantren berada dibawah binaan LDII yang kemudian pondok tersebut diberi nama Pondok Pesantren LDII Burengan.

Seiring waktu, pada 2010 LDII mengalihkan pengelolaan pondok pesantren kepada Yayasan Wali Barokah yang kemudian menjadi PP Wali Barokah. Penyerahan pengelolaan ini memiliki harapan agar pondok pesantren ini bisa meningkatkan fungsinya sebagai penghasil insan yang profesional religius. Sesuai dengan keinginan pendirinya yang ingin menyiarkan Agama Islam secara murni, mukhlis berpedoman kitab suci Alquran dan Alhadis dengan berlandaskan pada hak dasar kebebasan beragama yang dijamin oleh UUD 1945, maka diperjuangkanlah syiar Agama Islam dalam bingkai Negara Kesatuan Republik Indonesia (NKRI) sebagai kelanjutan perjuangan Bangsa Indonesia untuk mempertahankan dan mengisi kemerdekaan, mencapai cita-cita Bangsa Indonesia sebagaimana tercantum dalam Pembukaan UUD 1945, yaitu melindungi segenap Bangsa Indonesia dan seluruh tumpah darah Indonesia, memajukan kesejahteraan umum, mencerdaskan kehidupan bangsa, dan ikut serta melaksanakan ketertiban dunia yang berdasarkan kemerdekaan, perdamaian abadi dan keadilan sosial, mutlak diperlukan partisipasi dan peran serta dari segenap lapisan masyarakat Indonesia.

Memberikan peningkatan kehidupan beragama serta partisipasi pembangunan masyarakat untuk mewujudkan masyarakat yang adil dan makmur baik material maupun spiritual dan berakhlakul karimah bagi seluruh rakyat Indonesia.

PP Wali Barokah bagi Kota Kediri bukan hanya tempat menimba ilmu agama, namun telah menjadi ikon kota karena keberadaan menara setinggi 90 meter dengan kubah berlapis emas. Wali Kota Kediri H. A. Maschut yang menjabat pada 1999 hingga 2009 menyebutnya sebagai menara Asmaul Husna. Menara tersebut dibangun sejak 1 Januari 2000 hingga 23 Januari 2009-an diresmikan oleh Wakil Presiden RI H. M. Jusuf Kalla. Selain menjadi ikon kota kediri, menara Asma'ul Husna memiliki ruang perpustakaan yang menyimpan karya-karya para ulama Islam yang terdiri dari Alhadis, 
tafsir Alquran dan berbagai kajian fikih serta sejarah Islam.

Di menara ini pula terdapat kantor dan ruang kajian Majelis Taujih Wa Al-Irsyad, sebuah lembaga yang terdiri dari para ulama LDII. Mereka melakukan kajian terhadap berbagai kitab untuk memberikan solusi dari berbagai problematika umat Islam.

\section{Santri dan Ustad/Ustazah}

PP Wali Barokah Kediri, memiliki 3.994 santri. Para santri tersebut berasal dari seluruh penjuru wilayah di Indonesia. Di samping itu ada juga santri yang berasal dari mancanegara. Mereka datang dan mondok di pesantren ini, tentu dengan tujuan yang mulia yaitu untuk mencari ilmu pengetahuan Agama Islam yang memang lazim diajarakan di lembaga pendidikan Agama Islam yang disebut pondok pesantren. Di Pesantren juga bukan hanya diajarkan ilmu pengetahuan Agama Islam, tetapi secara otomatis mereka mendapatkan pendidikan akhlak, budi pekerti yang dilakukan sehari-hari oleh para santri dalam bentuk perilaku hubungan antara sesama santri, para santri dengan ustad/ustazah, baik sebagai guru maupun pengasuh pesaantren. Yang menarik dalam pendidikan tersebut setiap tahunnya diadakan kemah santri yang mengahdirkan seluruh santri LDII dari dalam negeri dan luar negeri. Dalam perkemahan santri tersebut, diisi pemberian materi tentang pendidikan akhlak, budi pekerti juga mengajarkan pendidikan kewarganegaraan dengan 4 pilar kebangsaannya.

Dalam interaksi itu, para peserta kemah terbiasa dan tertanam nilai-nilai budi luhur dan akhlak mulia dalam kehidupan sehari-hari dan dalam interkasi dalam lingkup masyarakat pesantren. Itulah salah satu ciri pesantren dalam menanamkan nilai-nilai agama dan kemasyarakatan tehadap para santri sebagai makhluk sosial. Dengan karakteristik model pendidikan demikian, maka lembaga pendidikan pesantren selalu diminati oleh para orang tua untuk mengirimkan anaknya belajar di pondok pesantren dalam upaya mencari ilmu pengetahuan agama dan pendidikan akhlak mulia. Begitu juga halnya dengan keadaan di PP Wali Barokah Kediri.
Rincian santri PP Wali Barokah yang berjumlah 3.994 orang, ditinjau dari jenis kelamin, terdiri dari 2.164 orang santri lakilaki, $(54,18 \%)$ dan 1,830 santri perempuan $(45,82 \%)$. Dilihat dari asal negara, berasal dari 10 negara yaitu: 1) Indonesia, 381 orang $(95,42 \%), \quad 2) \quad$ Malaysia 53 orang $(1,326 \%), 3)$ Singapura 29 orang $(0,726 \%)$, 4) Thailand 35 orang $(0,88 \%), 5)$ Kamboja 17 orang $(0.42 \%), 6)$ Philipina 30 orang $(0,75 \%), 7)$ Australia 16 orang $(0,40 \%), 8)$ Konggo 1 orang $(0,03 \%)$, 9) Prancis 1 orang $(0,03 \%)$ dan 10) Inggris 1 orang $(0,03 \%)$. Sebagai tuan rumah, santri Indonesia merupakan santri terbesar, berikutnya secara berturut-turtut Malaysia, Thailand, Philipina, Singapore, Australia, Kamboja, dan terakhir Konggo, Prancis, dan Inggris.

Dari jumlah santri 3.994 orang tersebut, dibagi menjadi empat kelompok. Keempat kelompok tersebut diberi inisial 1) Kelompok santri Cabe Rawit, berusia antara 5-12 tahun. Santri ini, usia pra sekolah hingga usia sekolah dasar/madrasah ibtidaiyah, 2) Kelompok santri Pemula usia >12-20 tahun atau digolongkan kelompok usia belajar pada Sekolah Dasar/Madrasah Ibtidaiyah hingga menengah atas, 3) Kelompok santri Terampil >20-30 tahun. Santri ini sudah selesai tingkat setara Aliyah dan di atasnya, seperti Ma'had Ali dan sudah dianggap trampil atau menguasai ilmu pengetahuan yang diajarkan selama mondok di pesantren. 4) Kelompok santri persiapan tes, yaitu santri yang sudah dalam bimbingan secara intensif untuk mengikuti tes akhir.

Materi yang dijadikan bahan tes yaitu penguasaan kandungan Alquran, dan hafalannya, penguasaan matan hadis dan kandungan matan hadis yang telah diajarkan selama mereka di pondok pesantren. Selain itu termasuk materi tes yaitu kemampuan berpidato. Bagi yang lulus dalam tes akhir, kelompok santri yang berasal dari dalam negeri Indonesia akan dikirim ke daerah asalnya, sedang santri yang berasal dari mancanegara akan dikirim ke negara asalnya untuk berdakwah.

Untuk mengajar para santri dengan pengelompokan tersebut, pada PP Wali Barokah ini ada 134 orang ustad/ustazah, 
terdiri dari 91 ustad dan 43 ustazah. Mereka diberi tugas untuk mengajar pada keempat kelompok santri tersebut. Untuk kelompok santri Cabe Rawit ditugaskan 42 orang ustad/ustazah, terdiri dari 30 ustad dan 12 ustazah. Untuk kelompok santri Pemula ditugaskan 37 ustad/ustazah, terdiri dari 27 ustad dan 10 ustazah. Selanjutnya untuk kelompok santri trampil ditugaskan 30 ustad/ustazah, terdiri dari 19 ustad dan 11 ustazah, sedang untuk kelompok santri Persiapan Tes ditugaskan 15 ustad dan 10 ustazah. Selanjutnya dapat dilihat pada Tabel 1.

Tabel 1. Kondisi santri dan Ustad/Ustazah

Jumlah santri

Pondok Pesantren Wali Barokah

\begin{tabular}{|c|c|c|c|}
\hline \multirow{2}{*}{ No } & \multirow{2}{*}{ Asal Negara } & \multicolumn{2}{|c|}{ Jumlah Santri } \\
\hline & & Pria & Wanita \\
\hline 1 & Indonesia & 2039 & 1772 \\
\hline 2 & Malaysia & 33 & 20 \\
\hline 3 & Singapura & 22 & 7 \\
\hline 4 & Tailand & 27 & 8 \\
\hline 5 & Kamboja & 13 & 4 \\
\hline 6 & Philipina & 19 & 11 \\
\hline 7 & Australia & 10 & 6 \\
\hline 8 & Kongo & 1 & \\
\hline 9 & Perancis & & 1 \\
\hline \multirow[t]{3}{*}{10} & London & & 1 \\
\hline & & 2164 & 1830 \\
\hline & Jumlah & \multicolumn{2}{|c|}{3994} \\
\hline
\end{tabular}

Jumlah Ustad

Pondok Pesantren Wali Barokah

\begin{tabular}{c|l|r|r}
\hline \multirow{2}{*}{ No } & \multirow{2}{*}{ Asal Negara } & \multicolumn{2}{|c}{ Jumlah Ustad } \\
\cline { 3 - 4 } & & \multicolumn{1}{c}{ Pria } & Wanita \\
\hline 1 & Kelompok Cabe Rawit & 30 & 12 \\
\hline 2 & Kelompok Pemula & 27 & 10 \\
\hline 3 & Kelompok Terampil & 19 & 11 \\
\hline 4 & Kelompok Persiapan Tes & 15 & 10 \\
\hline & & \multicolumn{2}{|c}{134} \\
\hline & & \multicolumn{2}{|c}{43} \\
\hline
\end{tabular}

Sumber Data : Dokumen Pesantren Tahun 2018

\section{Kurikulum Pesantren}

Kurikulum utama PP Wali Barokah adalah Alquran dan Alhadis dengan masa studi $1,5 \square 2$ tahun. Lulusannya akan menjadi juru dakwah pemula yang ditugaskan di tingkat Pengurus Anak Cabang (PAC) dan pengurus Cabang (PC) LDII di seluruh Indonesia. Selain kurikulum utama, PP Wali Barokah Burengan Banjaran Kediri merupakan 'pondok tradisional plus'. Dalam hal ini santri tidak hanya diberi pelajaran ilmu agama saja tetapi juga dibekali ketrampilan sehingga bisa tercipta sumber daya manusia yang trampil dan mandiri yang dilandasi iman dan taqwa kepada Tuhan. Secara umum dapat dikatakan bahwa sistem pendidikan di pondok pesantren ini bersifat non formal. Dalam hubungan ini, sistem pendidikan tidak mengenal adanya tingkatan formal dan akhir tahun ajaran. Para santri dikelompokkan atas dasar spesialisasi kitab dan daya serap ilmu yang diajarkan. Setiap santri yang sudah merasa siap, dapat mengajukan ujian untuk memperoleh kelulusan.
Ada berbagai kelompok pembelajaran sesuai dengan tingkat kompetensi masingmasing santri, mulai dari kelas anak-anak, pemula, hingga kelas untuk persiapan ujian. Paling tidak ada sembilan kelompok pembelajaran yaitu Cabe Rawit (usia 5 $\square 12$ tahun), Menulis Arab, Bacaan Alquran, Tafsir Lambatan Jawa, Tafsir Lambatan Indonesia, Tafsir Cepatan Jawa, Tafsir Cepatan Indonesia, Ujian/Tes, dan Lanjutan/Terampil.

Pada kelompok pembelajaran Cabe Rawit, pelajaran yang diberikan adalah hafalan doa-doa salat, praktik salat, hafalan doa harian, thoharoh, menulis huruf Arab dan Pegon, pendidikan akhlak. Pada kelompok pembelajaran Menulis Arab diajarkan mata pelajaran menulis huruf Hijaiyah, menulis Pegon, materi Pegon. Adapun kelompok pembelajaran bacaan Alquran diberi pelajaran tajwid dan materi bacaan. Sementara itu kelompok pembelajaran Tafsir Lambatan Jawa memberikan pelajaran kajian Alquran dan Hadis dalam Bahasa Jawa yang disertai dengan materi kelompok lambatan, 
sedangkan kelompok Tafsir Lambatan Bahasa Indonesia diberikan dalam Bahasa Indonesia. Demikian juga kelompok pembelajaran cepatan baik Bahasa Jawa maupun Bahasa Indonesia materinya sama hanya saja disampaikan dalam Bahasa Indonesia dengan ditambah materi kelompok cepatan.

Sementara itu kelompok pembelajaran ujian/test (tiga bulan) memberikan pelajaran lebih komprehensif yaitu: bacaan Alquran Qur'an, Tafsir Alquran, Metode Dakwah, Manajemen, Penyuluhan Hukum, Penyuluhan Kesehatan, dan Keputrian. Adapun kelompok pembelajaran Terampil/Lanjutan berlangsung selama 1 tahun dengan mendapatkan materi Tafsir Kutubussitah (Kajian enam kitab hadis sahih).

\section{Bahan Ajar}

Bahan ajar pokok yang digunakan dalam proses pembelajaran di PP Wali Barokah Burengan Banjaran Kediri adalah sumber asli Agama Islam yaitu Alquran dan Alhadis. Para kiai dan santri memanfaatkan kedua kitab itu sebagai sumber primer. Kitab- kitab yang sifatnya sekunder karya para ulama tidak digunakan. Memang betul bahwa hampir semua pondok pesantren mendasarkan diri pada Alquran dan Hadis, namun bahan ajar yang digunakan tidak langsung pada kajiankajian kedua kitab itu, tetapi menggunakan kitab-kitab sekunder karya para ulama besar terdahulu seperti kitab fikih, tauhid, dan sebagainya. Di samping kedua kitab utama itu juga diajarkan beberapa ilmu tambahan seperti ilmu tajwid, menulis Arab, Bahasa Arab, Nahwu, Shorof, Uhsul Fikih, Mustholah Hadis, dan sebagainya. Sementara itu materi ketrampilan terdiri dari berbagai kursus sesuai dengan bakat mereka. Sedangkan materi yang berkaitan dengan kemasyarakatan dan pemerintahan, pondok ini mengajarkan olahraga, bakti sosial, Bahasa Indonesia, metode dakwah, manajemen, dan sebagainya.

Kitab Alquran yang menjadi bahan kajian sama dengan kitab yang dipakai oleh masyarakat umum seperti terbitan Toha Putera, Gunung Agung, dan sebagainya. Seringkali kitab Alquran yang digunakan oleh para santri dan kiai berasal dari terbitan negara-negara Timur Tengah, khususnya
Beirut. Terbitan ini diperoleh ketika para santri menunaikan ibadah haji di Mekkah ataupun titip kepada calon haji untuk dapat dibelikan di sana. Kadang-kadang mereka memperoleh kitab itu dari oleh-oleh sahabat mereka yang baru saja datang dari Mekkah. Seringkali kitab-kitab terbitan luar negeri ini berfungsi ganda yaitu sebagai bahan ajar dan sekaligus sebagai kebanggaan yang dipajang di almari. Sudah barang tentu kitab- kiab hadis yang dibeli di Mekkah ataupun Madinah merupakan kitab-kitab hadis besar. Namun demikian ada juga yang memperoleh kitab itu dengan cara membeli dari toko-toko kitab di Indonesia.

Biasanya kitab Alquran yang dipakai oleh para kiai dan santri berupa kitab 'kosongan' dalam arti bukan kitab yang sudah diberi terjemahan. Para santri, khususnya santri pemula, lebih memilih kitab Alquran yang lembaran halamannya memiliki ruang yang lebar yang memungkinkan mereka dapat mengisinya dengan makna yang diajarkan oleh sang kiai di sela-sela di antara baris yang ada.

Bahan ajar pokok ke dua adalah kitabkitab hadis atau sunnah nabi. Kitab ini merupakan kitab yang dihimpun oleh para penghimpun hadis yang berisi segala pikiran, ucapan, tindakan dan tauladan Nabi Muhammad SAW. Kesaksian dari orangorang yang masih sempat berguru dengan pendiri PP Wali Barokah Burengan Banjaran Kediri yaitu KH Nur Hasan Al Ubaidah mengatakan bahwa kiai itu menguasai ilmu hadis (memberi makna dan keterangan) sebanyak 49 jenis himpunan hadis yang terdiri dari 6 hadis yang biasanya dikategorikan sebagai kutubussitah (yang tingkat kesahihannya diakui semua sekte Islam kecuali Syiah dan beberapa sekte yang mengingkari keabsahan hadis nabi) dan sisanya adalah berbagai hadis komplemen. Kitab-kitab hadis kutubussitah terdiri dari himpunan hadis yang disusun oleh Buchori, Muslim, Ibn Majjah, Abi Daud, Sunan Tirmidzi, dan Nasa'i.

Selain kitab-kitab hadis besar, juga dijumpai bahan ajar yang berupa kitab-kitab himpunan. Kitab himpunan merupakan cuplikan-cuplikan hukum-hukum atau dalil- 
dalil dari Alquran dan Hadis yang disusun berdasarkan bidang atau topic tertentu seperti Kitabussholah (kitab tentang salat), Kitabudda'awat (kitab kumpulan doa-doa), Kitabul Ilmi (kitab tentang kewajiban belajar ilmu agama), Kitabul Imaroh (kitab tentang keimaman), dan sebagainya. Berdbeda dengan kitab Alquran dan Hadis, kitab-kitab himpunan ini disusun sendiri oleh pondok pesantren. Dalil-dalil yang dituangkan dalam kitab-kitab himpunan ini merupakan dasardasar hukum yang kuat dan applicable.

Dilihat dari isinya, kitab-kitab himpunan ini merupakan pengantar bagi para pemula atau jamaah baru. Penggunaan kitab himpunan untuk para pemula ini didasari atas pertimbangan jika mereka langsung belajar dari kitab-kitab besar saja maka berbagai jenis amalan penting yang harus segera dilakukan tidak bisa segera diamalkan secara benar. Oleh karena itu jika ada jamaah baru maka di samping mereka mengkaji kitab-kitab besar, juga diberikan kitab-kitab himpunan agar dapat segera melakukan amalan-amalan secara benar sehingga jika meninggal sewaktu-waktu mereka sudah dalam pengamalan yang benar. Dalam hubungan itu kitab-kitab hadis besar merupakan bahan ajar pengayaan dan pendalaman.

Bahan ajar yang juga sangat penting dalam menjaga keimanan para santri adalah nasihat-nasihat ulama yang dituangkan dalam bentuk teks tertulis. Teks ini disebarluaskan dan menjadi bahan pembinaan baik bagi para santri di PP Burengan maupun warga LDII secara umum. Teks nasihat ini berisi nasihatnasihat dalam konteks mengatasi persoalanpersoalan aktual dengan meng- gunakan dasardasar hukum Islam yaitu Alquran dan Hadis. Dalam hukum Islam nasihat ulama merupakan salah satu bentuk dasar hukum Islam yang disebut ijma' atau ijtihad.

\section{Metode Pembelajaran}

Dalam Islam, pembelajaran pada hakekatnya adalah proses pemindahan pesanpesan dari satu orang kepada orang lain. Metode pembelajaran yang digunakan baik dalam pondok pesantren maupun pengajian di masjid-masjid yang diikuti oleh jamaah biasa adalah metode sebagaimana yang digunakan oleh Nabi. Jadi ada semacam gerakan pemurnian dalam metode pembelajaran. Dalam Agama Islam, sejak nabi Muhammad SAW dan para khalifah serta sahabat, proses pemindahan pesan-pesan yang terkandung dalam Alquran dan Hadis dilakukan melalui metode membaca, menulis, dan mendengar yang dalam ilmu komunikasi disebut sebagai verbal communication. Hal ini sesuai dengan sabda Nabi Muhammad SAW: 'Kalian mendengar (ilmu dariku), kemudian kalian didengar oleh murid kalian dan murid kalian didengar ole muridnya' (Hadis Riwayat Abu Dawud). Jadi metode transfer ilmu dalam PPB mencakup dua aspek sekaligus yaitu komunikasi lisan (oral communication) dan komunikasi tulisan (written communication).

Metode ini bukan hanya diterapkan di PP Wali Barokah Burengan Banjaran Kediri saja tetapi juga di seluruh pondok LDII maka para jamaah biasa sudah terbiasa dengan metode pembelajaran di pesantren. Materi yang disampaikan oleh mubalig itu berasal dari gurunya dan seterusnya sambungmenyambung hingga sampai kepada para sahabat dan Nabi. Demikian juga para santri akan menyampaikan bahan ajar itu kepada orang lain menjadi binaannya. Jadi metode pembelajaran ini saling mengikat secara keilmuan atau guru dan murid memiliki hubungan yang tiada terputus bagaikan rantai yang saling menyambung.

Dalam konteks ini, pelaksanaan metode pembelajaran Islam yang murni dan konsisten akan mengkondisikan kemurnian ajaran Islam itu sendiri. Metode ini menjauhkan pikiranpikiran ke arah reintepretasi terhadap hukumhukum Islam yang akan menimbulkan perpecahan-perpecahan agama. Memang ijtihad diakui sebagai salah satu dasar hukum tetapi ijtihad ini diarahkan untuk memberi jalan keluar terhadap persoalan-persoalan aktual dengan dasar hukum Alquran dan Hadis.

Sebaliknya pembelajaran yang islami ini juga dapat dilakukan dengan cara murid, karena mungkin murid sudah pandai, membacakan kitab, makna, dan keterangan. Sementara itu guru mendengarkan, membenarkan atau menyalahkan. Jika santri sudah membacakan kitab di hadapan guru dan 
jika sang guru bisa menerimanya maka ilmu sang murid sudah sah. Cara seperti ini disebut sebagai munawalah.

\section{Kegiatan Santri dan Masa Pembelajaran}

Para santri biasanya bangun atau dibangunkan pada pukul 02.00 dini hari untuk melakukan salat malam (salat tahajud, salat hajat, salat tasbih, dan sebagainya), dzikir, dan doa sepertiga malam yang terakhir yang diyakini merupakan waktu yang mustajab (manjur) untuk memanjatkan doa kepada Allah. Bagi santri yang tidak mengantuk dan masih memiliki semangat akan terus melakukan doa hingga menjelang waktu salat subuh. Setelah menunaikan salat subuh, para santri kemudian mengaji Alquran secara umum, yaitu bacaan, makna, dan keterangan. Pengajian yang diselenggarakan di masjid Baitil A'la ini diikuti oleh semua kelompok pembelajaran. Mereka duduk dengan santai di lantai masjid dengan memegang kitab mereka masing-masing. Kegiatan ini berlangsung hingga pukul 06.00. Setelah itu para santri kemudian istirahat. Pada umumnya mereka melakukan persiapan belajar dan ada juga yang mencuci pakaian. Mereka makan pagi mulai pukul 07.00.

Pelajaran dimulai pukul $08.00 \square 09.30$ sesuai dengan kelompok pembelajaran mereka masing-masing. Setelah istirahat selama setengah jam, mereka belajar lagi dari pukul $10.00 \square 11.00$. Setelah itu mereka diberi kesempatan untuk istirahat hingga salat dhohor. Kegiatan selanjutnya adalah makan siang dan istirahat hingga pukul 14.00. setelah itu mereka menerima pelajaran lagi hingga waktu salat asar sekitar pukul pukul 15.00. Setelah salat mereka istirahat sambil nderes atau memperdalam kitab secara sendirian ataupun dengan teman-teman kelompok ataupun sekadar membaca Alquran.

Setelah mandi dan makan sore mereka bergegas ke masjid untuk persiapan salat maghrib. Sambil menunggu imam salat, biasanya mereka membaca Alquran. Setelah salat maghrib dilanjutkan dengan nasihat dari pengurus pondok ataupun dari ustad. Kegiatan ini berlangsung hingga menjelang salat Isya'. Setelah salat Isya' dilanjutkan dengan pelajaran hingga pukul 10.00. Setelah itu para santri dipersilahkan untuk istirahat tidur. Namun demikian biasanya nderes terlebih dahulu sebelum tidur. Mereka dibangunkan pukul 02.00 malam. Apa yang menarik adalah setelah bangun mereka harus mengadakan apel sesuai dengan kelompok masing-masing dan diabsen untuk melakukan salat malam dan doa sepertiga malam yang terakhir.

Selain kegiatan harian sebagaimana yang digambarkan di atas juga ada kegiatan mingguan. Kegiatan ini khsusus untuk melatih santri agar dapat berorasi di depan publik. Kegiatan ini dilakukan setiap hari Jumat pukul 13.30 yang dilakukan secara berkelompok dan bergiliran. Tidak ada kegiatan bulanan secara khsusus di PP Wali Barokah Burengan Banjaran Kediri. Sementara itu kegiatan semesteran berupa khataman Alquran, kemudian enam bulan berikutnya khataman Alquran lagi, namun enam bulan berikutnya bukan khataman Alquran tetapi khataman khutubussitah (kitab hadis enam) dan setelah itu kembali khataman Alquran dan seterusnya. Biasanya kegiatan khataman ini bukan hanya diikuti oleh para santri yang ada di PPB tetapi juga dari pondok lain yang ada di seluruh Indonesia, bahkan tidak sedikit pula para warga LDII dari seluruh penjuru dunia yang memiliki kesempatan dan biaya akomodasi mengikuti kegiatan ini.

Kegiatan tahunan lain adalah pondok Ramadan. Kegiatan ini diisi dengan kajiankajian kitab secara marathon mulai setelah salat subuh pada pagi hari hingga pukul 22.00. Bahkan pada sepuluh hari terakhir di bulan Ramadan (malam lailatul qodar) kegiatan pengajian dilakukan hingga pukul 24.00. Jumlah santri pun juga mengalami peningkatan hampir dua kali lipat, karena banyak peserta yang berasal dari luar santri PP Wali Barokah Burengan Banjaran Kediri.

\section{Kegiatan Santri dan Akhir Pembelajaran Penugasan}

Para santri yang telah menamatkan pelajaran di PP Burengan biasanya langsung ditugaskan oleh pondok untuk mengabdikan ilmunya di masjid-masjid yang memang membutuhkan. Seperti diketahui bahwa 
masjid-masjid ini merupakan suatu unit komunitas terkecil yang sebetulnya secara langsung memiliki umat. Oleh karena itu para takmir masjid ini sebetulnya yang mengetahui secara pasti apakah mereka membutuhkan tambahan mubalig atau tidak. Mereka yang biasanya menyampaikn kebutuhan akan mubalig untuk kemudian pengurus pada tingkat kota atau kabupaten menyampaikan kepada Pondok Burengan. Pada saat sekarang ini sudah jarang satu masjid hanya memiliki satu mubalig. Kebanyakan setiap masjid sudah memiliki dua hingga 3 mubalig dan bahkan banyak pula yang memiliki tiga mubalig, terutama di kota-kota.

Selama penugasan pertama itu para mubalig pemula langsung terjun di masjidmasjid untuk melayani para jamaah. Mereka harus berkonsultasi dengan mubalig-mubalig setempat. Selain itu mereka juga harus berkoordinasi dengan para pengurus atau takmir masjid setempat dalam pelayanan umat. Demikian juga para mubalig muda ini harus melakukan pendekatan dengan para jamaah setempat beserta masyarakat yang ada di sekitar masjid yang mungkin hanya sebagian kecil yang ikut kegiatan pengajian di masjidmasjid LDII. Dengan demikian peran mubalig sangat signifikan dalam pembentukan citra warga LDII di tingkat lokal. Sang mubalig muda harus dapat bertindak sebagai suri tauladan bagi jamaah setempat.

Selama masa penugasan para mubalig muda ini biasanya tidak diperbolehkan pulang ke rumah orang tua. Mental mereka digembleng untuk terbiasa jauh dengan orang tua serta dapat mandiri. Suatu hal yang menarik adalah bahwa selama bertugas, kehidupan ekonomi mereka secara 'bil ma'ruf' atau secukupnya ditanggung oleh jamaah masjid yang dibinanya. Setelah masa penugasan selesai, mereka dibebaskan untuk pulang ke rumah orang tua. Untuk selanjutnya mereka harus siap untuk ditugaskan ke berbagai daerah baru jika mereka masih menginginkan. Untuk selanjutnya daerah (tingkat kota atau kabupaten) yang akan menentukan di masjid mana mereka harus mengabdi.

\section{Praktek Budi Luhur}

Dalam pembelajaran di PP Wali Barokah Burengan Banjaran Kediri ditekankan bahwa pemahaman terhadap Alquran dan hadis secara intelektual belum cukup. Para santri ditekankan untuk memiliki afeksi dan psikomotor Islami sebagai manifestasi dari pemahamannya terhadap hukum Islam. Jika pemahaman secara intelektual terhadap hukum Islam barangkali lebih berhubungan dengan kehidupan pribadi, tetapi aspek-aspek sikap dan tingkah laku lebih banyak berhubungan dengan orang lain. Aspek-aspek yang disebutkan terakhir inilah yang akan menciptakan pencintraan terahadp warga LDII. Tingkat penerimaan masyarakat terhadap gerakan yang dibawa oleh LDII sangat bergantung kepada aspek sikap dan tingkah laku para mubalig khususnya, dan warga LDII pada umumnya. Oleh karena itu PP Wali Barokah Burengan Banjaran Kediri selalu menekankan pentingnya memiliki budi luhur atau akhlaqul karimah bagi segenap warga LDII.

Praktik budi luhur di dalam masyarakat mencakup beberapa hal, antara lain mengagungkan dan taat kepada orang tua, mengagungkan pada para ulama, budi luhur terhadap sesama muslim, dan budi luhur terhadap masyarakat dan lingkungan sekitar. Sikap mengagungkan dan taat kepada orang tua (selagi tidak perintah maksiat) merupakan amal sholih dan sekaligus perintah dari Allah, meskipun orang tua itu bukan seorang muslim. Praktik budi luhur kepada orang tua anatara lain bertutur-kata dengan bahasa yang halus atau sopan, bila disuruh segera melaksanakan jika tidak, berarti maksiyat, bila seorang anak dinasehati, harus mendengarkan dan tidak memotong pembicaraan, senang membantu pekerjaan orang tua di rumah, tidak bohong dan jujur kepada mereka, dan sebagainya.

Bersikap mengagungkan kepada para ulama merupakan suatu kewajiban. Kepada para santri dan warga LDII selalu ditekankan tentang pentingnya sikap mengagungkan kepada para pengurus. Hal ini berkaitan dengan kepercayaan bahwa mereka memiliki andil yang besar dalam mencerdaskan masyarakat. Para ulama dan mubalig juga merupakan 'wasilah' atau perantara bagi ilmu- 
ilmu Islam. Beberapa contoh sikap dan prilaku yang menunjukkan sikap mengagungkan ulama antara lain: memanggil dengan panggilan yang sopan, berbicara dengan nada suara yang rendah, jika ulama berbicara maka harus mendengarkan, tidak membelakanginya ketika sedang dalam pengajian, jika ulama berbuat kesalahan ketika mengajar tidak boleh dihina, dan sebagainya.

Terhadap sesama muslim juga dikembangkan sikap budi luhur. Sesama muslim harus dibangun sikap ukhuwah islamiyah atau persaudaraan dalam Islam. Di dalam pembelajaran di PP Burengan, semangat persaudaaan Islam ini betul-betul sangat ditekankan. Hal ini antara lain dapat dilihat dari semangat dan sikap bahwa harta sesama muslim adalah haram untuk diambil secara tidak sah, sesama muslim tidak boleh saling menghina dan menjatuhkan namanya. Di samping itu ditekankan bahwa sesama muslim tidak boleh saling membunuh. Ajaran moral yang Islami semacam ini sangat menarik sebagai bekal yang berarti bagi santri alumni PP Wali Barokah Burengan Banjaran Kediri.

Keberadaan warga LDII di tengahtengah masyarakat bagaikan ikan yang berada di dalam air. Oleh karena itu pembinaan akhlak di PP Wali Barokah Burengan Banjaran Kediri juga selalu menekankan betapa pentingnya para alumni pondok membangun hubungan baik dan kemitraan dengan masyarakat di mana mereka mengabdikan ilmu agamanya. Mereka yakin bahwa dakwah dengan perbuatan (da'wah bilhal) menjadi sarana yang hebat untuk mnyebarkan Islam. Beberapa ajaran dalam kaitannya dengan budi luhur kepada masyarakat antara lain: apabila bertemu dengan tentangga menyapa, apabila melewati sekelompok masyarakat menyapa dengan sopan, melayat warga yang minggal dengan memberikan sumbangan, menjenguk tetangga yang sakit, ikut berpartisipasi dalam kerja bakti, meminta izin jika tidak bisa mengikuti kegiatan RT, menyadari kekurangan dan mudah memaafkan, dan sebagainya.

Di samping itu ajaran moral yang betulbetul ditekankan di PP Wali Barokah Burengan Banjaran Kediri dan bahkan di masjid-masjid LDII yang lain adalah adanya enam tabiat luhur yang mencakup rukun, kompak, kerjasama yang baik, jujur, amanah, muzhid (hemat). Dengan 'doktrin' moral ini diharapkan para alumni PP Burengan betul-betul menjadi warga masyarakat dan warga negara yang baik yang akan mampu menciptakan iklim kedamaian dalam masyarakat.

\section{Hubungan dengan Masyarakat Sekitar dan Pemerintah}

Organisasi Islam Lembaga Dakwah Islam Indonesia (LDII) terus melakukan sosialisasi dan transformasi kepada publik agar masyarakat pada umumnya bisa lebih mengetahui terkait LDII. Salah satu upaya tersebut adalah dengan menggelar media gathering untuk mengajak rekan media turun langsung meninjau beberapa pondok pesantren yang ada di bawah naungan LDII. Seperti kunjungan ke PP Wali Barokah, Kediri, Jawa Timur. Wartawan halopolisi.com bisa langsung melihat aktvitas para santri dan santriwati yang berada di pondok pesantren tersebut. "Alhamdulillah, cukup banyak intensitas kunjungan ke PP kami. Sudah ada sekitar 25 provinsi dari 34 Provinsi yang sudah berkunjung di sini. Mereka ada dari MUI, Kementerian Agama, unsur Pemerintah. Melakukan berbagai kajian dan setelah mereka ke sini, mereka justru mendapatkan ilmu baru dan paham apa dan bagaimana LDII," kata Suparjo, bidang humas PP Wali Barokah, yang juga disaksikan oleh umar shodiq. Selasa (03/7/2018).

Untuk meyakinkan bahwa PP Wali Barokah tidak seperti yang dipikirkan orang, Suparjo mengajak kami berkeliling pondok. Terlihat para santri sedang mengaji. Bergegas, tim pondok pesantren dan para pewarta beranjak di masjid yang berada tepat di belakang pondok. Sekali lagi tidak ada yang berbeda. Salat yang dilakukan seperti umat Muslim pada umumnya. "Ya, sampean lihat sendiri, tidak benar jika ada orang lain salat di masjid LDII terus dibersihkan. Semua sesuai syariat Islam," urai pria yang juga menjadi Dewan Pembina DPW LDII Jawa Timur ini sembari tersenyum. Setiap tahun, PP Wali Barokah meluluskan 400-500 Dai pemula. Total jumlah santri yang ada terdapat \pm 4.000 santri. Semuanya tidak hanya dari Indonesia, tapi juga luar negeri. 
Sebagaimana yang dijelaskan sebelumnya bahwa pesantren bukanlah symbol dari 'elitisasi' ilmu Islam. Dalam hubungan itulah PP Wali Barokah Burengan Banjaran Kediri berusaha untuk menghilangkan kesan adanya keterpisahan antara pondok pesantren dengan masyarakat di sekitarnya. Di bidang ekonomi, PP Wali Barokah Burengan Banjaran Kediri meluncurkan program ekonomi mandiri dengan cara mendirikan UB (Usaha Bersama) yang merupakan unit retail yang bukan hanya melayani warga pondok namun juga melayani masyarakat di sekitarnya.

Selain itu di bidang kemasyarakatan PP Wali Barokah Burengan Banjaran Kediri juga menjalin hubungan yang sinergis dengan pemerintah kabupaten Kediri untuk memperkuat ukhuwah antara ulama dengan umara. Bukti yang dapat dikemukakan di sini adalah keikutsertaan PP Wali Barokah Burengan Banjaran Kediri dalam lembaga Paguyuban Antar Umat Agama dan Kepercayaan kepada Tuhan Yang Maha Esa. Lembaga ini merupakan badan kerjasama antar umat beragama dalam mengatasi berbagai persoalan yang harus dipecakan bersama-sama.

Sebagaimana telah diuraikan sebelumnya, bahwa PP Wali Barokah Kediri, memiliki 3.994 santri. Dari jumlah santri tersebut, 3.811 orang $(95,40 \%)$, berasal dari Indonesia yang merupakan jumlah mayoritas terbesar santri. Sedang sisanya berasal dari 9 negara di luar Indonesia, dengan jumlah santri keseluruhannya sebanyak 183 orang $(4,60 \%)$.

Berikut ini hasil rangkuman dari kuesioner atas respon dari para santri luar negeri yang yang belajar di PP Wali Barokah Kediri.

\section{Orientasi Belajar Santri Asing}

Berkenaan dengan tujuan para santri belajar di PP Wali Barokah, diproleh jawaban banwa tujuan mereka belajar di PP ini untuk mendapatkan ilmu Agama Islam secara baik, benar dan lengkap (kaffah), bersumber dari kitab-kitab yang muktamad (dapat dipertanggungjawabkan) secara akademis. Para santri merasa puas dengan ilmu agama yang diajarkan di PP Wali Barokah. Pembelajaran yang sederhana dapat diterima dengan mudah. Sebagai contoh ketika membahas materi salat, maka seluruh kitab tentang salat akan diuraikan seluruhnya. Oleh karena itu menurut pendapat mereka tujuan santri belajar di PP Wali Barokah sudah tepat.

\section{Alasan Santri Asing Belajar di Pesantren}

Dari beberapa santri yang ditanya apa alasan belajar di PP Wali Barokah? jawaban mereka adalah bahwa mereka belajar di pondok pesantren karena seluruh keluarga mereka juga menimba ilmu pengetahuan Agama Islam dari pesantren. Dan dengan belajar di pondok peantren keluarga atau saudara-saudaranya itu menjadi orang yang berilmu atau memiliki ilmu pengetahuan Agama Islam. Ternyata dari para santri asing yang belajar di pondok Wali Barokah memiliki latarbelakang keluarga yang belajar di pesantren Indonesia, baik orang tuanya maupun saudara-saudara mereka. Dan sebagian santri juga ada yang dikirim oleh lembaga seperti MUIS, Al-Ma'arif dan Wathoniyah di Asia Tenggara. Dan sebagian yang lain alasan mereka belajar di pondok pesantren untuk pendalaman ilmu Agama Islam. Dengan pendalaman ilmu agama tersebut mereka dapat menjalani hidup dan kehidupan ini betul-betul sebagai seorang Islam dan memahami perintah Allah dan Rasulnya secara baik dan benar.

\section{Kitab yang Diajarkan Dan yang Disukai}

Mengenai kitab apa saja yang digunakan di pondok pesantren sebagai sumber belajar ilmu Agama Islam mereka meresponnya bahwa kitab yang diajarkan adalah kitab Fikih, yaitu: Minhajus Salikin, Al Ghayatu Wat Taqrib, Matan Az Zubad, 'Umdatul Fighi, Zaadul Mustaqni Fikhtisharil Muqni, Akhsharul Mukhtasharat, Ad Durarul Bahiyyah Fii Masa-il Fiqhiyyah, Jami'ul Ummahat, Al Wajiz Fi Fiqhis Sunnati Wal Kitabil 'Aziz, Al Mulakhash Al Fiqhi, Fiqhus Sunnah, Tamaamul Minnah Fit Ta'liqi 'Ala Fiqhis Sunnah, Shahihu Fiqhis Sunnah Wa Adillatuhu Wa Taudhihuhu, Madzabihil A- immah, Al Ikhtiyarat Al Fiqhiyyah, Al Ikhtiyarat Al Fiqhiyyah Lil Imam Al Albani ,Fiqhus Sunnah Al Muyassar, Al Fiqhul Muyassaru Fi Dhauil Kitabi Was Sunnati, Asy Syarhul Mumthi' 'Ala Zadil 
Mustaqni' ,Ad Darari Al Mudhi-ah Syarhud Duraril Bahiyyah, Syarhu Umdatil Fiqhi, Al Mughni Fil Fiqhil Hambali, Al Majmu' Syarhul Muhadzab dan Al Mausu'ah Al Fiqhiyyah Al Kuwaitiyyah. Sedangkan kitab Tafsir yaitu: Tafsir Al- Jalalain. Tafsir Ibnu Katsir, Tafsir Al Kasysyaf, Tafsir Al-Maraghi dan Tafsir Al-Mizan. Kitab tauhid yaitu kitab Fariidah al-Faraaid fii Ilm al-'Aqaaid. Kitab aqidah dengan kajian tentang adalah: Aqidah Ilahiyah dan Al-Aqidah al-Nabawiyyah, dan lainnya. Selain itu ada kitab berbentuk modul pembelajaran yaitu: Kitabus Sholah, Kitabus Solatin Nawafil, Kitabul Da'awat, Kitabul Adab, Kitabul Sifati Jannah Wa nar, Kitabul Ahkam, Kitabul Janaiz, Kitabul Adillah, Kitabul Hajji dan Kitabul Jihad, Kitabul Manasikil Haji, Kitabus Shoum, Kitabul Manasiki Wal Jihad, Kanzil Umal dan serangkain contoh kutbah hari Jumat ataupun hari besar.

Adapun kitab yang disukai santri selain kitab hadis yang 6 yaitu: Imam Bukhari, Imam Muslim, Imam Nasai, Imam Abu Dawud, Imam Turmudzi, dan Imam Ibnu Majah, mereka ada yang cenderung untuk mendalami ilmu fikih, dan ada pula yang cenderung mendalami kajian Alquran dan ilmu Alquran. Selain kitab tersebut di atas santri juga diajarkan kitab nahwu dan sorof.

\section{Persepsi dan Ekspektasi Santri Asing Belajar di Pesantren}

Di pesantren, tentunya pesantren yang berada dibawah asuhan para ustad/ustazah memiliki sanad keilmuan yang jelas. Segala yang dipelajari di pesantren bias dipertanggungjawabkan. Jika kita runtut, ilmu yang dikonsumsi alurnya jelas sampai kepada Nabi Muhammad SAW. Oleh karenanya, kita tidak perlu khawatir atas kebenaran ilmu yang dipelajari di pesantren. Karena itu sudah sesuai dengan tuntunan Nabi Muhammad SAW yang dikemudian hari akan dipertanggungjawabkan di hadapan Allah Yang Maha Esa. selain pesantren mengajarkan kita untuk tidak berpikir oposisi-binner. Sebuah gaya berpikir yang selalu mempertentangkan setiap perbedaan. Di pesantren kita diajarkan bahwa perbedaan itu adalah sunnatullah. Perbedaan tidak perlu dipertentangkan, akan tetapi disikapi secara arif agar bisa berjalan beriringan. Di pesantren kita diajarkan bagaimana bersosial. Tanpa disadari, dalam kehidupan santri menyimpan segudang pelajaran hidup. Hal sederhana, semisal bagaimana santri makan bersama dengan menggunakan talam. Dari situ kita bisa melihat, bahwa kebersamaan dalam pesantren itu sangat diutamakan. Tanpa melihat dari mana asalnya, miskin, kaya bahkan keturunannya. Pesantren tak pernah mengenal kasta, semua diperlakukan sama. Dan hal paling penting yang bisa didapat dari pesantren adalah "Akhlak". Akhlak yang dimaksud di sini bukan sekedar persoalan etika semata. Karena etika lebih kepada persoalan pola sikap dan pola ucap. Semisal, seorang koruptor yang sosialnya bagus tidak bisa dikatakan berakhlak. Karena apa yang ia lakukan tidak sesuai dengan kebenaran hatinya. Akan tetapi, akhlak jauh melampaui itu. Seseorang yang berakhlak, baik tindakan, perkataan, pikiran maupun perasaannya akan berjalan secara beriringan. Keempatnya tidak mungkin bertentangan. Contoh yang bisa kita ambil, ketika Nabi Muhammad SAW mengutuk seseorang yang munafik. Seperti kita mafhum, munafik adalah seorang yang ucapan dan tindakan, pikiran serta hatinya tidak sesuai. Dari contoh itu bisa kita petik, bahwa akhlak meliputi persoalan pola sikap, pola ucap, pola pikir dan pola rasa (hati). Bagaimanapun juga, Nabi Muhammad SAW diutus ke dunia, tak lain dan tak bukan untuk menyempurnakan akhlak manusia, Innama bu'itstu liutammima makarimal akhlaq.

Oleh karena pernyataan para santri bahwa belajar di pondok pesantren dengan harapan mendapatkan ilmu pengetahuan yang dapat membimbing hidup di dunia berdasarkan ajaran agama yang dapat membawanya masuk surga. Selain itu ilmu pengatahuan yang diperolehnya dari pondok pesantren dapat diajarkan kepada anakanaknya dan masyarakat yang membutuhkannya. Adapun ekspektasi belajar di PP Wali Barokah, para santri menjawab dapat mengkahatamkan atau menyelesaiakan salah satu dari Kitab Kutub Sittah dari ustad/ustazah yang mengajarknya. Kutub Sittah adalah himpunan sejumlah Kitab Referensi tentang Hadis Rasul yang disusun para Imam Hadis yaitu, Imam Bukhari, Imam 
Muslim, Iman Nasai, Imam Abu Dawud, Imam Turmudzi, dan Imam Ibnu Majah. Bagi mereka yang utama dapat menghafal Alquran lengkap 30 Juz. Di PP Wali Barokah memang pondok yang hanya mengajarkan ilmu agama, yang lulusannya diharapkan dapat berdakwah menyiarkan Agama Islam. Kitab yang utama dan wajib diajarkan adalah Kutubussittah. Jadi kebanyakan santri asing yang datang ke pondok tersebut adalah untuk belajar ilmu agama yang sumber utamanya kitab Kutubussittah.

Begitu juga dengan ekspektasi orang tua atas anaknya belajar di PP Wali Barokah, bahwa orang tua mereka berharap agar anakanaknya menjadi manusia mandiri dalam kehidupannya di masa depan, menjadi orangorang yang berakhlak mulia di sisi Allah, dan mampu mengembangkan ilmu yang diperolehnya dari pondok pesantren, khususnya untuk keluarga, masyarakat dan bangsanya jika diperlukan.

Ekspektasi negara asal santri, nampaknya santri belajar ke Indonesia atas keinginan pribadi, tidak ada campur tangan negara. Ada sebagian kecil mereka diutus atas nama lembaga, tentunya lembaga dapat membantu mencerdaskan masyarakat di mana mereka nantinya berada.

\section{Layanan Santri Asing di Pesantren}

Layanan bagi santri asing secara khusus tidak ada, seluruh santri di PP Wali Barokah diperlakukan sama tidak ada yang berbeda. Akan tetapi pesantren menyediakan les khusus bagi mereka yang ingin belajar Bahasa Indonesia maupun Bahasa Arab, bahkan Bahasa Jawa. Dari beberapa santri luar negri yang kami temui, mereka sudah ada yang lancar berbahasa Indonesia dan ada yang masih terbata-bata dalam mengucapkan Bahasa Indonesia. Akan tetapi justru menurut mereka lebih mudah mengucapkan dengan Bahasa Jawa. Bahkan ada satu santri dari Kongo sangat fasih sekali menggunakan Bahasa Jawa Kromo Inggil.

Keberadaan di pesantren Jawa, sangatlah wajar jika mereka lebih baik dalam menggunakan Bahasa Jawa, karena lingkungan yang memaksa menggunakan mereka bahasa daerah tersebut. Sedang
Bahasa Arab kelihatannya tidak diwajibkan bagi meraka untuk digunakan di PP Wali Barokah, seperti halnya di pondok-pondok pesantren lainnya yang mewajibkan pengggunaan bahasa tersebut.

Mengenai tanggapan para santri atas ketersediaan sarana dan rasarana yang tersedia di pondok pesantren, diperoleh respon bahwa PP Pesantren Wali Barokah tempat mereka mondok, memiliki cukup sarana belajar yang sangat memadai den mampu menunjang pelaksanan proses belajar mengajar.

\section{Sumber Pembiayaan}

PP Wali Barokah yang didirikan oleh KH. Nur Hasan Al Ubaidah dan Ahmad Ibroham, tahun 1951, dikenal dengan sebutan Darul Hadis Burengan. Pondok pesantren menampung \pm 4.000 siswa/santri baik dari berbagai propinsi di Nusantara, maupun dari Manca Negara.

Pada tahun 2010 pengelolaan pondok pesantren berada di bawah Yayasan Wali Barokah yang kemudian diberi nama Pesantren Wali Barokah. Keberadaannya di bawah yayasan ini dengan harapan agar pesantren dapat meningkatkan fungsinya sebagai penghasil insan yang profesional religius, penyebar Agama Islam secara murni, mukhlis, berpedoman pada kitab suci Alquran dan Al- Hadis, dalam upaya memperjuangkan syiar Agama Islam dalam bingkai Negara Kesatuan Republik Indonesia (NKRI), sebagai upaya mempertahankan dan mengisi kemerdekaan, Republik Indonesia.

Dengan jumlah santri yang tergolong cukup banyak ini, sudah barang tentu mmerlukan anggaran dan biaya cukup besar untuk keperluan, baik keperluan hidup para santri sehari-hari dan keperluan proses belajar mereka. Sementara itu Pimpinan Ponfok Pesantren sudah mencanangkan bahwa bagi para santri yang mondok di Pesantren ini tidak dikenai biaya alias gratis, selama mereka bekajar. Seluruh keperluan para santri ditangungung oleh pondok pesantren.

Anggaran belanja dan biaya pendidikan untuk keperluan penyelenggaraan pondok pesantren dihimpun dari 3 (tiga) sumber dana, yaitu Pengurus Yayasan dan pondok pesantren, 
orang tua para santri, dan donatur. baik besrsifat temporer atau permanen (berkesinambungan) dari berbagai kalangan masyarakat, instansi pemerintah atau swasta, baik dalam bentuk bantuan finansial atau bentuk barang-barang untuk kebutuhan pembangunan sarana belajar dan tenpat tinggal para santri. Sedangkan dari orang tua santri yang mampu, diminta untuk memberikan infak atau sedekahnya sesuai dengan kemampuannya masing-masing. Sementara itu dana dikumpulkan juga dari donatur tetap yang secara berkala menyumbangkan sejumlah harta kekayaannya kepada pondok pesantren. Para donatur ini, umumnya dari kalangan pengusaha, para agniya (orang kaya) baik dalam bentuk zakat atau sumbangan yang berkelanjutan.

\section{Peran Pemeritah}

Untuk pelakasanaan pengawasan secara teknis, ada ketentuan yang disebut dengan Tatakerja dan Sinergitas Tim Pengawasan Orang Asing yang disingkat TIM PORA. Tim ini melibatkan berbagai unsur di antaranya, Kemenkumham, Pemerintah Daerah, Kementerian Agama, Dinas Pendidikan, Dinas Pariwisata dan Dinas Tenaga Kerja Transmigrasi dan Kependudukan. Menurut Peraturan Pemerintah No. 31 Tahun 2013, tim tersebut memiliki tugas mengawasi, melindungi dari segi keamanan dan ketertiban bagi siapa saja (warga negara asing) yang tinggal di wilayah negara Indonesia.

Mereka memiliki tugas masing-masing, namun tugas yang secara tegas dan lugas, terkait dengan keberadaan para santri asing yang berada di pondok pesantren di Kabupaten Kediri, yaitu peran Kementerian Agama dan Kemenkumhan, dalam hal ini diwakili oleh Keimigrasian. Kebijakan yang dibuat oleh Kementerian Kumham/Keimigrasian disebut dengan kebijakan selektif melalui pendekatan kesejahteraan dan keamanan. Kebijakan itu diberikan kepada orang asing yang dapat memeberikan manfaat bagi kesejahteraan rakyat bangsa dan negara RI, serta tidak membahayakan keamanan dan ketertiban, juga tidak bermusuhan baik terhadap rakyat maupun NKRI yang berdasarkan Pancasila dan UUD 1945.
Dalam koridor ini, para santri yang belajar di Pontren Wali Barokah memang murni untuk ikut belajar dan menimba ilmu pengetahuan semata, dan tidak ada maksud lain selaian untuk belajar. Namun demikian, untuk melindungi dan mengawasi mereka selama berada di Indnoesia dari segi keamanan dan ketertiban, berada di bawah Keimigrasian. Mengingat mereka/parasantri berada di tingkat Kabupaten/Kota, kewenangan pengamanannya berada di bawah Kantor Imigrasi Kabupaten Kota, dan Kepala Kantor Imigrasi Kabupaten/Kota selaku Ketua. Hal ini sdebagaimana tertuang pada Pasal 194, Peraturan Pemerintah No 31 tahun 2013.

Di samping itu mereka juga secara legal berada di Indonesia, di bawah koordinasi instansi resmi yang menyelenggaraan pendidikian Agama dan Keagamaan yaitu Kementerian Agama. Dalam konteks ini untuk memberikan legalitas keberadaan mereka selama mengikuti pendidikan di pondok pesantren, pihak pondok pesantren tempat mereka belajar mengajukan permohonan Surat Ijin Tinggal Sementara melalui Kementerian Agama kepada Kantor Imigrasi Kabupaten Kota. Berdasarkan permohonan tersebut pihak Kementerian Agama merekomendasikan ke Kantor Imigrasi Kabupaten Kediri agar para santri yang belajar dan tinggal di Pesantren Wali Barokah Kediri yang jumlahnya sebanyak 183 orang, memili Surat Ijin sementara selama mereka belajar di Pesantren dimaksud. Hal itu dilakukan mengingat Kementerian Agama sebagai salah satu instansi yang ditetapkan menjadi anggota TIM PORA, selain NaKer Transduk, Pariwisata dan Pendidikan.

Prinsip tugas dari Tim Pora yaitu kebersamaan, keterpaduan, keterbukaan dan kemitraan dalam menangani atau mengatasi masalah yang dihadapi berkaitan dengan keberadaan orang asing ini. Berdasarkan prisnsip kerja tersebut, masing-masing anggota tim mempunyai tugas sesuai dengan instansinya untuk memberikan saran dan pertimbangan kepada instansi atau lembaga pemerintah terkait dengan pengawasan orang asing tersebut. 
\begin{tabular}{ccc}
\hline Berkenaan dengan & pengawasan \\
dimaksud, terbagi & kepada dua jenis
\end{tabular} pengawasan, preventif, dan refresif. Pengawasan preventif yaitu mengantisipasi dan berupaya melakukan pencegahan serta pembinaan sesuai tugas dan fungsi masingmasing instansi. Sedangkan pengawasan refresif yaitu kegiatan menangani masalah yang terjadi melalui penegakan hukum, imigrasi, kepolisian dan kejaksaan. Ada banyak masalah kerawanan yang terjadi dengan pengawasan orang asing. Di antara kerawanan itu, melebihi jangka waktu ijin tinggal terbatas (over stay) dan ijin tinggal tidak sesuai dengan peruntukannya.

Berkenaan dengan tugas TIM PORA tersebut, dalam hal ini Kementerian Agama sebatas "mengawasi" keberadaan para santri yang statusnya resmi dan legal mengikuti ketentuan yang berlaku serta status mereka cukup jelas sebagai para santri pondok pesantren. Dalam hal ini Pondok Pesanatren itupun selaku lembaga resmi penyelenggara pendidikan memiliki aturan dan ketentuan yang cukup ketat dalam pelaksanaan atau penyelenggaraan pendidikan. Dengan kata lain keberadaan mereka para santri sebagai orang asing Insyaa Allah dijamin tidak melakukan hal-hal yang dkategorikan pada pelanggaran yang telah ditetapkan oleh instani berwenang.

\section{PENUTUP}

Pondo Pesantren Wali Barokah Kediri memiliki 3.994 santri. Dari jumlah santri tersebut, 3.811 orang $(95,40 \%)$, berasal dari Indonesia yang merupakan jumlah mayoritas terbesar santri. Sedang sisanya berasal dari 9 negara di luar Indonesia, dengan jumlah santri keseluruhannya sebanyak 183 orang $(4,60 \%)$. Tujuan para santri belajar di PP Wali Barokah, untuk mendapatkan ilmu Agama Islam secara baik, benar dan lengkap (kaffah), bersumber dari kitab-kitab yang muktamad (dapat dipertanggungjawabkan) secara akademis. Para santri merasa puas dengan ilmu agama yang diajarkan di PP Wali Barokah. Pembelajaran yang sederhana dapat diterima dengan mudah.

Alasan mereka belajar di PP Wali Barokah, karena seluruh keluarga mereka juga menimba ilmu pengetahuan Agama
Islam dari pesantren. Dengan belajar di pondok peantren keluarga atau saudarasaudaranya itu menjadi orang yang berilmu atau memiliki ilmu pengetahuan Agama Islam. Ternyata dari para santri asing yang belajar di Pondok Wali Barokah memiliki latarbelakang keluarga yang belajar di pesantren Indonesia, sebagian santri juga ada yang dikirim oleh lembaga seperti MUIS, AlMa'arif dan Wathoniyah di Asia Tenggara. Santri lainnya beralasan, mereka belajar di pondok pesantren untuk pendalaman ilmu Agama Islam.

Persepsi santri belajar di PP Wali Barokah dengan harapan mendapatkan ilmu pengetahuan yang dapat membimbing hidup di dunia berdasarkan ajaran agama yang dapat membawanya masuk surga. Selain itu ilmu pengatahuan yang diperolehnya dari pondok pesantren dapat diajarkan kepada anakanaknya dan orang (masyarakat) yang membutuhkannya.

Berkenaan dengan ekspektasi para santri belajar di PP Wali Barokah, mereka menjawab dapat mengkahatamkan atau menyelesaiakan salah satu dari kitab Kutub Sittah dari ustad/ustazah yang mengajarknya. Ekspektasi orang tua atas anaknya belajar di PP Wali Barokah, mereka berharap anakanaknya menjadi manusia mandiri dalam kehidupannya di masa depan, menjadi orangorang yang berakhlak mulia di sisi Allah, dan mampu mengembangkan ilmu yang diperolehnya dari pondok pesantren, khususnya untuk keluarga, masyarakat dan bangsanya jika diperlukan. Ekspektasi negara asal santri, nampaknya santri belajar ke Indonesia atas keinginan pribadi, tidak ada campur tangan negara. Ada sebagian kecil mereka diutus atas nama lembaga, tentunya lembaga berharap dapat memanfaatkan pengetahuan yang diperoleh para utusannya di lembaga tersebut.

Sarana dan Prasarana sangat memadai. untuk biaya hidup para santri selama menempuh ilmu di PP Wali Barokah, sepenuhnya ditanggung oleh pondok pesantren penyelenggara pendidikan alias gratis. Sedang sumber pembiayaan dari pengurus, dermawan dan dari hasil usaha yang mereka kembangkan. 
Peran pemerintah dalam melayani segala kebutuhan para santri asing selama berada di PP Wali Barokah dilakukan dengan membentuk Tim Pengawasan Orang (TIM PORA).

\section{DAFTAR PUSTAKA}

Abdul Mujib, dan Muhaimin. 1993. Pemikiran Pendidikan Islam. Bandung: PT. Trigenda Karya.

Abdul Majid. 2009. Perencanaan Pembelajaran Mengembangkan Standar Kompetensi Guru. Bandung: Remaja Rosdakarya Offset.

Abasri. 2007. Sejarah dan Dinamikan Lembaga-Lembaga Pendidikan Islam di Nusantara: Surau, Menuasah, Pesantren dan Madrasah. Dalam Nizar, Samsul (Eds.), Sejarah Pendidikan Islam Era Rosululloh Sampai Indonesia. Jakarta: Kencana. (hlm. 279296).

Abdullah Idi. 2011. Pengembangan Kurikulum Teori dan Praktik. Jogjakarta: ArRuzz Media.

Alben Ambarita. 2006. Manajemen Pembelajaran. Jakarta: Departemen Pendidikan Nasional.

Anwar, Sumarsih. 2007. Modernisasi Sistem Pendidikan ditinjau dari Penerapan Kurikulum Pemerintah (Studi pada Pondok Pesantren Al-Islam, Bangka Belitung). Dalam Harapandi Dahri (Prawacana), Modernisasi Pesantren. Jakarta: Departemen Agama RI Balai Penelitian dan Pengembangan Agama. (hlm. 205-242).

Ansyar, Mohammad. 1989. Dasar-dasar Pengembangan Kurikulum. Jakarta: Departemen Pendidikan dan Kebudayaan, Direktorat Jenderal Pendidikan Tinggi Proyek Pengembangan, Lembaga Pendidikan Tenaga Kependidikan.

Binti, Mainah. 2009. Tradisi Intelektual Santri. Yogyakarta.Teras.

Departemen Agama Islam Republik Indonesia Direktorat Jenderal Kelembagaan
Agama Islam. 2003. Pondok Pesantren dan Madrasah Diniyah Pertumbuhan dan Perkembangan. Jakarta.

Djamaroh. Syaiful Bahari. 2006. Strategi Belajar Mengajar. Jakarta: PT Rineka Cipta.

Eryna, dkk, 2014, “Analisis Kualitas Layanan Pendidikan" Proseding Seminar Pendidikan Nasional, Univeritas Sebelas Maret, Surakarta.

Ghazali, M., Bahri. 2003. Pesantren Berwawasan Lingkungan. Jakarta: Prasasti.

Mahmud. 2006. Model-Model Pembelajaran di Pesantren. Jakarta: Media Nusantara.

Moleong, Lexy J. 2013. Metologi Penelitian Kualitatif. Bandung: PT. Remaja Rosda Karya.

Muhammad Fathurrohman, dan Sulistyorini. 2014. Esensi Manajemen Pendidikan Islam. Yogyakarta: Teras.

Muliawan Jasa Ungguh. 2015. Ilmu Pendidikan Islam. Jakarta: PT Raja Grafindo Persada. Mulyasa. 2006. Kurikulum Tingkat Satuan Pendidikan. Bandung: PT Remaja Rosdakarya.

Nana Sudjana. 2008. Dasar-Dasar Proses Belajar Mengajar. Bandung: Sinar Baru Algensindo.

Nazarudin. 2007. Manajemen Pembelajaran. Yogyakarta.Teras.

Nurul Anam, dan Ahmad Mutohar. 2013. Manifesto Modernisasi Pendidikan Islam Dan Pesantren. Yogyakarta: Pustaka Pelajar.

Oemar Hamalik. 2003. Kurikulum dan Pembelajaran. Jakarta: Bumi Aksara.

2012. Manajemen

Pengembangan Kurikulum. Bandung: Remaja Rosdakarya. Purwanto. 2014. Evaluasi Hasil Belajar. Yogyakarta: Pustaka Pelajar.

Pondok Pesantren Wali Barokah, (Online), (http://www.Wali Barokah.org/), diakses 01 Juli 2018. 
Peta Kota Kediri, (online), Google Maps, diakses: 4 April 2012. Kota Kediri, (http:id.wikipedia.org/wiki/Kota_Kediri ), diakses: 01 Juli 2018.

Puslitbang Pendidikan Agama dan Keagamaan, 2018. Hasil Survey Santri Luar Negeri. Jakarta

Tim peneliti Puslitbang Pendidikan Agama dan Keagamaan, 2018, "Desain Operasional penelitian Santri Asiang di Pondok Pesantren" Badan Litbang dan Diklat Kementerian Agama RI.
Toha, Muhammad, 2014, Orientasi Santri Dalam Menempuh Pendidikan Pesantren Di Pamekasan" Dosen STAIN Pamekasan.

Qomar Mujamil. 2004. Manajemen Pendidikan Islam. Erlangga.

Qowaid. 2007. Pemikiran Pendidikan Islam. Jakarta: Pena Satria. 